\title{
Em favor do cinema indisciplinar: o caso português
}

Carolin Overhoff Ferreiral

1. Professora da UNIFESP, com pós-doutorado sênior da ECANUSP e doutorado da Universidade Livre de Berlim. É autora do livro Novas Tendências na Dramaturgia Latinoamericana (Berlim, 1999) e Identity and Difference - Postcoloniality and Transnationality in Lusophone Films (Zurique/Munique/Londres, 2012), e organizadora dos livros 0 Cinema Português através dos Seus Filmes (Porto, 2007) e On Manoel de Oliveira (Londres, 2008). 


\section{Resumo}

O cinema como lugar de estéticas que possibilitam um pensamento heterodoxo possui uma longa tradição. Desde o cinema mudo, filmes exploram e transgridem as fronteiras disciplinares, expondo a construção de suas ficções. Nas últimas duas décadas, esse fenômeno, evidente em cineastas consagrados como Chris Marker, Harun Farocki, Jean-Luc Godard e Eduardo Coutinho, entre muitos outros, tem sido cada vez mais discutido através do conceito de ensaio fílmico ou filme-ensaio. Partindo de uma discussão desse conceito, este artigo pretende introduzir outro, o de filme indisciplinar, e, para evidenciá-lo, traçar sua presença no cinema português. Os filmes escolhidos para testar o novo conceito são Douro, faina fluvial (1931) e Acto da primavera (1963), ambos de Manoel de Oliveira, Catembe (1965), de Faria de Almeida, e Jaime (1974), de António Reis.

\section{Palavras-chave}

Ensaio fílmico, filme indisciplinar, cinema português 


\section{Abstract}

Since its silent beginnings film has been a site for heterodox thinking and transgression of disciplinary boundaries by exposing the construction of fictions. Recently, filmmakers like Chris Marker, Harun Farocki, Jean-Luc Godard or Eduardo Coutinho have therefore been associated to the essay film. However, this article proposes a new concept for film studies, the indisciplinary film. It is inspired in Jacques Rancière's idea of philosophy as a field of knowledge that thinks, at its best, between disciplines, as well as in his texts on the aesthetic regime. To prove my point I will analyse four Portuguese films: Douro, Faina Fluvial (1931) de Manoel de Oliveira, Acto da Primavera (1963) de Manoel de Oliveira, Catembe (1965) de Faria de Almeida e Jaime (1974) de António Reis.

\section{Keywords}

Essay film, indisciplinary film, Portuguese cinema 


\section{Introdução}

No final dos anos 1980, surgiu na Alemanha (MÖBIUS, 1991; KANZOG, 1991; BLÜMLINGER; WULFF, 1992; HATTENDORF, 1994; SCHERER, 2001, entre outros) e na França (NOGUEZ, 1977; BELLOUR, 1990; BELLOUR; ROTH, 1997, entre outros) um renovado interesse pelo conceito de filme-ensaio ou ensaio fílmico. Ao longo de uma década, a discussão do conceito se espalhou pela Europa (APRÀ, 1997; ORTEGA; WEINRICHTER, 2006; RASCAROLLI, 2009) e chegou, no novo milênio, à América do Sul e à América do Norte (ALTER, 2006; CORRIGAN, 2011), produzindo uma bibliografia considerável. No Brasil, o conceito está sendo discutido por André Brasil (2006), Consuelo Lins (2006; 2008), Arlindo Machado (2006), Cezar Migliorin (2010), Ismail Xavier (2009), entre outros.

É de conhecimento comum que o conceito de ensaio foi introduzido por Michel de Montaigne, em seu famoso livro cujo título traz o termo no plural. ${ }^{2}$ Procurando apresentar "sem máscaras" o pensamento e a "essência" do seu autor (MONTAIGNE, 1993: 34), Os ensaios esboçam, como explicita Arthur Franz (1993: 17), uma Lebenskunst, ou seja, uma arte de viver e conviver com as imperfeições humanas. O mapeamento das especificidades do ser humano surge da auto-observação e da reflexão, ao mesmo tempo em que leva o autor a abdicar de regras e esquematismos, da idealização ou da tipificação. Apesar desse ímpeto “indisciplinar” (RANCIÈRE, 2006), o ensaio tornou-se gênero influente nas mais diversas disciplinas, seja na filosofia, seja nas ciências, seja nas artes - entre elas, o cinema.

A suspensão de uma ideia tradicional de método tornou-se ainda mais fulcral quando, no início do século XX, George Lukács (1978) e, depois, Theodor W. Adorno (2003) retomaram a discussão do conceito, no contexto de uma revisão generalizada da objetividade das ciências. Embora discordasse de Lukács na possibilidade de pensar

2. Laura Rascaroli (2009: 30) sugere que o ensaio é uma tradição literária bem mais antiga, remontando a Cícero e Sêneca. 
ano 1 número 2

Temáticas

Livres

o ensaio como forma artística, Adorno (2003: 28) o cita longamente para sublinhar o contributo do ensaio a um pensamento não ortodoxo, que se contenta com as limitações do conhecimento, em vez de defender uma verdade absoluta, como acontece nas disciplinas científicas através de seus métodos:

Em relação ao procedimento científico e sua fundamentação filosófica enquanto método, o ensaio, de acordo com sua idéia, tira todas as conseqüências da crítica ao sistema. Mesmo as doutrinas empiristas, que atribuem à experiência aberta e não antecipável a primazia sobre a rígida ordem conceitual, permanecem sistemáticas na medida em que definem condições para o conhecimento, concebidas de um modo mais ou menos constante, e desenvolvem essas condições num complexo o mais homogêneo possível. Desde Bacon - ele próprio um ensaísta - o empirismo, não menos que o racionalismo, tem sido um "método". Nos processos do pensamento, a dúvida quando ao direito incondicional do método foi levantada quase tãosomente pelo ensaio. Este leva em conta a consciência da não-identidade, mesmo sem expressá-la; é radical não no não-radicalismo, ao se abster de qualquer redução a um princípio e ao acentuar, em seu caráter fragmentário, o parcial diante do total. "O grande Sieur de Montaigne talvez tenha sentido algo semelhante quando deu a seus escritos o admiravelmente belo e adequado título de Essais. Pois a modéstia simples é uma altiva cortesia. O ensaísta abandona suas próprias e orgulhosas esperanças, que tantas vezes o fizeram crer estar próximo de algo definitivo: afinal, ele nada tem a oferecer além de explicações de poemas dos outros ou, na melhor das hipóteses, de suas próprias idéias. Mas ele se conforma ironicamente a essa pequenez, à eterna pequenez da mais profunda obra do pensamento diante da vida, e ainda a sublinha com sua irônica modéstia."

Comparando os dois autores e suas reflexões sobre o ensaio, percebe-se que há mais pontos em comum do que divergências. Com efeito, ambos distinguem a centralidade do autor como local de experiência intelectual, através da qual o ensaio articula suas dúvidas e sua crítica perante os métodos das disciplinas científicas que se socorrem na obrigação "pré-crítica de produzir definições” (LUKÁCS, 1978: 2). Quando Lukács 
(1978: 2) fala em "monólogo reflexivo" e "pathos existencial do autor", Adorno (2003:

35) usa a imagem do autor como palco de interrogações e dúvidas:

\begin{abstract}
O pensador, na verdade, nem sequer pensa, mas sim faz de si mesmo o palco da experiência intelectual, sem desemaranhá-la. Embora o pensamento tradicional também se alimente dos impulsos dessa experiência, ele acaba eliminando, em virtude da sua forma, a memória desse processo. O ensaio, contudo, elege essa experiência como modelo, sem entretanto, como forma refletida, simplesmente imitá-la; ele a submete à mediação através da sua própria organização conceitual; o ensaio procede, por assim dizer, metodicamente sem método
\end{abstract}

Em sua definição do ensaio como lugar de pensamento performático, mediado pelo autor, Adorno reconhece que a linguagem estética do ensaio participa das possibilidades não conceptuais da obra de arte. Julga, porém, impossível que se torne como esta, porque entende a arte como sendo não discursiva.

Um ponto de vista parecido, mas mais bem apurado, no que diz respeito à diferença entre arte e filosofia é proposto por Gilles Deleuze e Félix Guattari (2001: 13), que definem a filosofia como "arte de formar, de inventar, de fabricar conceitos”. Essa definição parte da preocupação dos autores com os "rivais" da disciplina, encabeçados pela sociologia, que ambicionam participar da vocação filosófica de criar conceitos. Cientes de que cada campo do conhecimento é criativo, Deleuze e Guattari (2001: 13) mantêm-se firmes em relação à especificidade da missão da sua disciplina: "as ciências, as artes, as filosofias são igualmente criadoras, mesmo se compete apenas à filosofia criar conceitos no sentido estrito". Não há dúvida para os autores de que apenas "a filosofia tira conceitos (que não se confundem com idéias gerais ou abstratas), enquanto a ciência tira prospectos (proposições que não se confundem com juízos), e a arte tira perceptos e afectos (que também não se confundem com percepções ou sentimentos)" (DELEUZE; GUATTARI, 2001: 37). O que eles 
ano 1 número 2

Temáticas

Livres

colocam em pauta não é que a arte seja incapaz de pensar, mas a forma como ela o faz: "A arte não pensa menos que a filosofia, mas pensa por afectos e perceptos" (DELEUZE; GUATTARI, 2001: 88).

A ideia de um ensaio fílmico não entra em choque com essa definição. Parece, no entanto, que a possibilidade de pensar através da arte, ou, mais especificamente, através de sons e imagens, indiscutível para Deleuze e Guattari no final do século XX, não o era em seu início. Estudando os diferentes textos produzidos por cineastas e teóricos de cinema sobre o ensaio fílmico, sobressai a vontade de demonstrar que o cinema é, de fato, um lugar de reflexão. Sergei Eisenstein foi o primeiro diretor a apropriar-se do ensaio, ao classificar assim o seu filme Outubro (1928), para alegar que o cinema tinha a "possibilidade de articular idéias" (EISENSTEIN apud SCHLEGEL, 1975: 290).

Baseando-se em Eisenstein, Béla Balázs (1972) especificou, em 1930, que no Gedankenfilm (filme de pensamentos, denominado também por ele como ensaio fílmico ou ensaio montado) o abstrato era mediado de forma sensível e o intelectual, através do efeito da imagem - posição que ressoa em Deleuze e Guattari (2001). Na mesma linha, Hans Richter (apud BLÜMLINGER, 1992) considerava o filme-ensaio, já em 1940, uma muito desejada variação do documentário, capaz de visualizar pensamentos, tornando visível uma ideia invisível. Deu como exemplos os filmes ingleses de Alberto Cavalcanti, Basil Wright e John Grierson, bem como os filmes de diretores que trabalhavam junto com Jacques Brunius, na França, ou Henri Storck, na Bélgica.

Quase uma década mais tarde, em 1948, Alexandre Astruc(apud BLÜMLINGER, 1992) ainda não conseguiu apontar um único filme que merecia ser considerado uma expressão do pensamento, mas não duvidava dessa hipótese. Ponderava que esse tipo de filme possuiria um caráter dinâmico e dialético e abrangeria (um detalhe significativo) filmes ficcionais. 
Poucos anos mais tarde, em 1955, Jacques Rivette (1977) analisou Viagem à Itália (1954), de Roberto Rossellini, como exemplo de um ensaio, sugerindo que o cinema era tão capaz de ser ensaístico quanto a literatura. Na opinião do crítico e futuro cineasta, Rossellini tinha filmado suas ideias, bem como os detalhes mais comuns do dia a dia (RASCAROLI, 2009: 26). ${ }^{3}$

Logo em seguida, em 1958, André Bazin (apud BLÜMLINGER, 1992) deparou-se, no mesmo ano em que Adorno publicou o seu influente artigo, com um filme que se enquadrava na definição de Astruc: Carta da Sibéria, de Chris Marker. Em sua análise, Bazin concentrou-se nos perceptos, ou seja, na dialética entre som e imagem, e na montagem do olho para a orelha, que cunhou de montagem horizontal. Estava convencido de que esse tipo de montagem podia levar o documentário a um novo patamar.

Alexander Kluge, Edgar Reitz e Wilfried Reinke (apud BLÜMLINGER, 1992), por sua vez, retomaram em 1965 o pensamento de Balázs ao focarem a relação dialética entre percepção e conceito em filmes que julgavam capazes de articular ideias complexas. No mesmo ano, Jean-Luc Godard (apud LIANDRATGUIGUES, 2004: 9) cunhou o seu filme O demônio das onze horas como um ensaio fílmico. A expressão dele de que o cinema era uma "forma que pensa" associou-o, como poucos cineastas, ao conceito, idealizando, como novidade, uma certa autonomia do material fílmico.

Para o contexto latino-americano, Fernando Solanas e Octavio Getino (1976) apontaram, no final dos anos 1960, em seu famoso manifesto sobre o Terceiro Cinema, que o filme-ensaio era uma linguagem privilegiada para o desenvolvimento desse cinema (RASCAROLI, 2009: 29). A possibilidade de articular estética e política surgia, por meio desses autores, numa chave revolucionária.

3. Laura Rascaroli também menciona os escritos de Cesare Zavattini sobre cinema pessoal que datam dos anos 50 e 60, bem como o conhecido texto de Pier Paolo Pasolini sobre "cinema poético", de 1965. 
ano I número 2

Temáticas

Livres

A literatura mais recente define o filme-ensaio com base nesses autores, ou através de análises de filmes, como uma obra de arte aberta, que foge a uma fixação dentro dos parâmetros dos gêneros já estabelecidos. A subjetividade do ponto de vista e a autorreflexividade são referidas como características de filmes que resistem à passividade na recepção, pois procuram envolver o espectador na renovação do relacionamento entre sons e imagens. Há consenso sobre o fato de que o questionamento dos limites de gêneros e mídias possibilita um encontro entre literatura, filosofia e mídias visuais que desconhece hierarquias (MÖBIUS, 1991; BLÜMLINGER; WULFF, 1992; MACHADO, 2006; RASCAROLI, 2009; CORRIGAN, 2010).

Há discordância apenas em relação à definição do ensaio fílmico como gênero cinematográfico próprio. Enquanto para alguns ele é assumidamente uma forma narrativa basilar do mundo moderno (SCHERER, 2001), em pé de igualdade com os gêneros de ficção, não ficção e cinema experimental, outros o consideram um antigênero que escapa a qualquer tipo de definição, pois atravessa e reorganiza todos os gêneros e subgêneros existentes (KROHN, 1992; ALTER, 2006; RASCAROLI, 2009). Seguindo essa segunda linha de pensamento, Volker Pantenburg realça que o ponto de vista subjetivo, que constitui a matriz do ensaio fílmico, mina, de fato, qualquer possibilidade de classificá-lo como tal. Pelo contrário, significa "um adeus implícito aos princípios de uma definição de gênero" (PANTENBURG, 2006: 152). Com base nas reflexões dos diretores e teóricos referidos acima, o autor sugere que o ensaio fílmico deveria ser definido menos por seu lado formal, isto é, pela "voz" do autor que complementa a “imaturidade (Unmündigkeit) da imagem” (PANTENBURG, 2006: 154). Em vez de discutir a relação entre som e imagem na tradição de Bazin, seria preciso enfocar a existência de elementos na linguagem imagética que possuem um potencial teórico que incide com a exploração da montagem. Os estudos de caso de Pantenburg, filmes de Harun Farocki e Jean-Luc Godard, apontam para a tentativa desses cineastas de pensar com imagens sobre imagens. 
Suzanne Liandrat-Guigues participa também da revisão do conceito, mas de outro ângulo. A autora argumenta que o objetivo primordial do ensaio fílmico advém menos da ocupação de um "entre" ficção e documentário do que da vontade de "fazer compreender a conversão de signos cinematográficos realizados por um certo tipo de cinema" (LIANDRAT-GUIGUES, 2004: 11). Chama a atenção para a diversidade dos ensaios audiovisuais, que vão desde um ceticismo perante a imagem de um Jean-Luc Godard a um "novo tipo de reflexão, totalmente imprevisível" (LIANDRAT-GUIGUES, 2004: 12). Novamente, remetendo-nos para Montaigne, Adorno e Lukács, a autora compara o ensaio fílmico com as ciências exatas, explicitando a sua dimensão experimental e a sua intenção de oferecer experiências em vez de fatos "duros", sendo que "o ensaio é frequentemente descrito por uma abordagem que não se submete às regras disciplinares, às regras da argumentação e da demonstração" (LIANDRAT-GUIGUES, 2004: 8).

A breve revisão bibliográfica demonstra que, além de instrumento para defender a faculdade racional do cinema, o afastamento do pensamento disciplinar surge como a característica principal do ensaio, ao mesmo tempo que as disciplinas se apropriaram dele para defini-lo como gênero ou lugar discursivo. Julgo que o conceito da indisciplinaridade de Jacques Rancière, referido brevemente acima, proporciona a oportunidade de devolver ao ensaio a sua irreverência, bem como de construir uma nova perspectiva sobre o papel da arte na contestação de métodos disciplinares.

Citei Adorno e a ideia dele de que o ensaio utilizava um método antimetódico para combater o pensamento tradicional, ao mesmo tempo que questionava a capacidade da arte de atuar nesses moldes. Ambas as afirmações tiveram um efeito pouco favorável para o debate. Rancière (2006: 6) sugere, contrariamente, que uma disciplina não se define a priori pelos seus métodos, mas pela "constituição de um objeto como objeto de pensamento e [pel]a demonstração de uma certa 
ano 1 número 2

Temáticas

Livres

ideia de conhecimento - em outras palavras, uma certa ideia da relação entre conhecimento e a distribuição de posições". De fato, o autor argumenta que a ciência (referindo-se às ciências humanas e sociais) não é nada mais do que "uma máquina de guerra contra a alodoxia [falso julgamento]. Mas o que ela chama de alodoxia é de fato um dissenso estético" (RANCIÈRE, 2006: 6). Dito de outro modo, as disciplinas do conhecimento tentam neutralizar tudo o que foge do consenso e o que ameaça o equilíbrio, tudo o que coloca em risco a distribuição dos papéis ou das ocupações numa sociedade, aquilo que o autor denomina como partilha do sensível (RANCIÈRE, 2009).

Nessa lógica, o maior objetivo das ciências humanas e sociais versa sobre o estabelecimento de relações estáveis através de fronteiras que regulam o dissenso, e essas fronteiras ocultam o fato de que os métodos se desdobram na construção de histórias. A indisciplinaridade é, por sua vez, uma forma de pensamento que revela as fronteiras estabelecidas pelas disciplinas, bem como a função delas como instrumentos de "guerra". O neologismo articula a ideia de que qualquer método, em vez de examinar um território, procura defini-lo por meio de histórias contadas sobre ele. Qualquer área de conhecimento, como a filosofia, precisa dirigir a sua atenção às fabulações das outras disciplinas denominadas métodos - para garantir a sua indisciplinaridade:

O pensamento disciplinar diz: nós temos nosso território, nossos objetos e métodos correspondentes. Assim falam a sociologia, a história, as ciências políticas ou a teoria literária. Assim também fala a filosofia, em sentido geral, quando posa como disciplina. Mas no momento em que quer fundarse como disciplina das disciplinas, ela produz esta inversão: a fundação da fundação é uma história. E a filosofia diz para os conhecimentos que estão seguros de seus métodos: métodos são fábulas recontadas. Isto não significa que sejam inválidos. Significa que eles são armas em uma guerra; não são instrumentos que ajudam a examinar um território, senão armas que servem para estabelecer fronteiras. (RANCIÈRE, 2006: 11) 
Ao contrário de Deleuze e Guattari (2001), Rancière não diferencia as diversas disciplinas do conhecimento. É tão somente a construção de histórias que as distingue: "Não existe fronteira garantida que separe o território da sociologia do da filosofia, ou da história da literatura. [...] Só a linguagem das histórias consegue traçar uma fronteira, separando a contradição da ausência de uma última razão das razões das disciplinas" (RANCIÈRE, 2006: 11). Atribuindo à política um fundamento estético, Rancière também a inclui em sua lista. Entendendo-a como mais uma das áreas de expressão humana que se ocupa de contar histórias, aponta a ficcionalidade como elo comum entre política, arte e ciências humanas e sociais, que define a nossa percepção do mundo: "A política e a arte, tanto quanto os saberes, constroem 'ficções', isto é, rearranjos materiais dos signos e das imagens, das relações entre o que se vê e o que se diz, entre o que se faz e o que se pode fazer" (RANCIÈRE, 2009: 59).

O autor associa a indisciplinaridade, que desvenda a construção das ficções, sobretudo à filosofia. Mas é também possível argumentar que a arte possui esse potencial - a arte do "regime estético", principalmente. Ao empregar um conceito da filosofia para definir a arte, esse outro conceito basilar do pensamento rancieriano revoga as fronteiras entre ambas, embora o seu objetivo maior seja a substituição da ideia de uma arte moderna e o prolongamento do seu regime. Logo, o ponto de viragem para o regime estético é localizado através de duas referências: por um lado, no idealismo alemão e, por outro, no realismo literário.

A arte do regime estético pode ser qualificada como sendo indisciplinar, pois se retrai da inteligibilidade da imitação de uma ação para realçar a matéria bruta dos objetos e o potencial narrativo dela:

E seu momento inaugural foi com frequência denominado realismo, o qual não significa de modo algum a valorização da semelhança, mas a destruição dos limites dentro dos quais ela funcionava. Assim, o realismo romanesco é antes de tudo a subversão das hierarquias da representação 
ano 1 número 2

Temáticas

Livres

(o primado do narrativo sobre o descritivo ou a hierarquia dos temas) e a adoção de um modo de focalização fragmentada, ou próxima, que impõe a presença bruta em detrimento dos encadeamentos racionais da história. (RANCIÈRE, 2009: 32)

Rancière (2009: 36) argumenta que o regime estético como questionamento dos limites da semelhança ganhou expressividade através de filósofos e artistas como Giambattista Vico, G.W.F. Hegel, Friedrich Hölderlin, Honoré de Balzac e Felix Mendelssohn, citados sem discriminação de suas áreas de atuação. Não obstante, um texto literário, Madame Bovary, de Gustave Flaubert, serve de exemplo para especificar a grande reviravolta que o regime representa.

Trata-se de uma nova ficcionalidade que "se desdobra sempre entre dois polos: entre a potência de significação inerente nas coisas mudas e a potencialidade dos discursos e níveis de significação" (RANCIÈRE, 2009: 55). Portanto, as obras do regime estético possuem uma sensibilidade específica que se diferencia dos regimes anteriores - o regime da ética da imagem e o regime representativo - porque demonstra sempre esse potencial heterogêneo: "produto idêntico ao não produto, saber transformado em não-saber, logos idêntico a um pathos, intenção do inintencional, etc." (RANCIÈRE, 2009: 32). ${ }^{4}$ A heterogeneidade implode fronteiras preestabelecidas e propõe novas experiências, reconfigurando a partilha do sensível.

Um livro que não possui traços da intervenção do autor e exibe, em vez disso, apenas a indiferença e a passividade das coisas sem vontade ou significado. Pensamento não é entendido como uma faculdade que impõe a sua vontade em seus objetos, mas como uma faculdade de se tornar idêntico com o seu contrário. (RANCIÈRE, 2006a: 117)

4. Aqui encontramos também um ponto de partida para aliar o ensaio cinematográfico ao novo realismo, pois, no contexto do regime estético, o cinema não é pensado em termos ontológicos, como o queria André Bazin (1991), senão sempre de forma heterogênea, isto é, abrangendo a razão dos fatos e a razão das ficções. 
Seguindo esse raciocínio, as obras artísticas que pertencem ao regime estético podem ser consideradas indisciplinares. O seu objetivo principalé produzir dissenso. É preciso especificar que dissenso não significa contestação, mas divergência do consenso estabelecido, com o fim de reorganizar a partilha do mundo sensível:

\begin{abstract}
Assim o dissenso, antes de ser oposição entre um governo e as pessoas que o contestam, é um conflito sobre a própria configuração do sensível. [...] a distribuição dos espaços privados e públicos, dos assuntos que nele se trata ou não, e dos atores que têm ou não motivos de estar aí para deles se ocupar. Antes de ser um conflito de classes ou de partidos, a política é um conflito sobre a configuração do mundo sensível na qual podem aparecer atores e objetos desses conflitos (RANCIÈRE, 1996: 373).
\end{abstract}

A política deixa de ser associada a conceitos como poder, conflito (entre forças antagônicas) ou dominação. Em vez disso, é vinculada à dimensão estética, compreendida como percepção do mundo. Essa percepção, por sua vez, entende-se que seja tanto cognitiva quanto sensível. Não existe diferença entre recepção ativa e passiva:

que confirma ou transforma essa distribuição das posições. O espectador também age, como o aluno ou o cientista. Observa, seleciona, compara, interpreta [...]. É nesse poder de associar e de dissociar que reside a emancipação de cada um de nós enquanto espectador. Ser espectador não é a condição passiva que devêssemos transformar em atividade. É a nossa situação normal. (RANCIÈRE, 2010: 22-28)

Não é difícil encontrar as mais diversas manifestações de dissenso no ensaio fílmico, bem como a tentativa de entender o espectador como um ser complexo ao qual são oferecidas, através do potencial heterogêneo dos filmes, novas experiências. O contributo de Laura Rascaroli (2009) para a teorização do ensaio fílmico tem sido precioso, pois torna isso mais patente quando sublinha o interesse do ensaio no diálogo: 
ano I número 2

Temáticas

Livres
Em outras palavras, a estrutura do filme ensaio (bem como do ensaio literário) é uma interpelação constante; cada espectador, como indivíduo ou membro de uma audiência coletiva e anônima, é convidado a participar no relacionamento dialógico com o enunciador para tornar-se ativo, intelectual e emocionalmente, para interagir com o texto [...] o filme ensaio é a expressão de uma voz singular e autoral que entra em diálogo com o espectador. (RASCAROLI, 2009: 35-37)

Entendendo o filme-ensaio como forma de arte do regime estético, Rascaroli possibilita uma outra abordagem da questão da autoria, pois a subjetividade perde sua centralidade ao resultar de um encontro com a realidade e com os objetos dela - objetos esses que possuem uma potência de significação própria, à qual, no caso do cinema, a filmagem oferece a oportunidade de se manifestar.

Perante os mais recentes trabalhos sobre o ensaio fílmico e a consciência da heterogeneidade dos filmes, pode parecer desnecessária a substituição de um conceito com oito décadas de tradição por outro. No entanto, ao aliar o filme indisciplinar ao regime estético, torna-se possível mudar a perspectiva sobre o cinema em geral e sobre o ensaio fílmico em especifico, porque o conceito realça: 1) a finalidade de revelar a construção de ficções através da heterogeneidade (de temporalidades, do alto e do baixo, do popular e do erudito, da razão dos fatos e da razão das ficções); 2) a sua dimensão política através da produção de dissenso estético; e 3) a recepção ao mesmo tempo cognitiva e sensível, ativa e passiva.

Consequentemente, os debates em torno da classificação do ensaio fílmico como gênero, da obstinação com a sua capacidade de pensar, da insistência na atividade do espectador, da definição do potencial de significação como posição autoral, do questionamento da fronteira entre realidade e ficção e da importância dada à relação inovadora entre som e imagem tornam-se desnecessários. Apontar o filme indisciplinar como parte do regime estético possibilita, além disso, participar da reavaliação da ideia de um cinema moderno, ao qual o ensaio 
fílmico está associado. Dessa forma, é possível enquadrá-lo numa tradição maior, que teve o seu início pelo menos na viragem do século XVIII para o século XIX.5 Isso permite entender o cinema como parte de uma vertente estética em estreito diálogo com outras formas artísticas, ou seja, serve também como comentário sobre o debate acerca da especificidade do cinema.

Sendo assim, procuro estabelecer o cinema indisciplinar como instrumento analítico, cuja utilidade será testada através de um estudo de caso: o cinema português. Este reúne em sua não tão extensa filmografia um número considerável de filmes cuja "sensibilidade específica" visa propor novas experiências e, através delas, reconfigurar o consenso estabelecido. Através da análise de quatro filmes, pretendo ainda revisar, de forma indireta, algumas ideias genéricas sobre a história do cinema português. O argumento de Rancière (2009: 35) de que "o regime estético das artes é o verdadeiro nome daquilo designado pela denominação confusa de modernidade" serve como norte deste empreendimento.

\section{Filmes indisciplinares portugueses}

\section{Douro, faina fluvial}

É possível dizer com Rancière que a montagem intelectual do filme Outubro (1928), de Eisenstein, supostamente o primeiro ensaio fílmico, participa da afirmação do regime estético no cinema. Regime esse que "não começou com decisões de ruptura artística. Começou com as decisões de reinterpretação daquilo que a arte faz ou daquilo que a faz ser arte" (RANCIÈRE, 2006: 36). O que o 
ano 1 número 2

Temáticas

Livres

cinema faz ser arte, nesse caso, é a montagem de sequências que reconstroem a Revolução Russa de 1917 com objetos simbólicos cuja presença "bruta" oferece indícios para reinterpretar o fato histórico. ${ }^{6}$ Constrói-se uma narrativa "fragmentada" que anseia ocupar o lugar da historiografia.

Ao abolir as fronteiras disciplinares entre a construção de uma história cinematográfica e um comentário histórico, o filme pode ser reclamado para o cinema indisciplinar, junto com outros filmes de montagem, como "as sinfonias das metrópoles": Berlim - Sinfonia de uma metrópole (1927), de Walter Ruttmann, O homem com a câmera (1929), de Dziga Vertov, e À propos de Nice (1931), de Jean Vigo, que participaram igualmente da reinterpretação da arte cinematográfica ao se declararem crônicas, ou mesmo composições visuais, da contemporaneidade urbana. Esses filmes exploram, através do ritmo acelerado da montagem, no espaço das grandes metrópoles europeias, o encontro entre os corpos que as habitam e as máquinas que as movimentam, indagando das mais diversas formas essa "identidade de contrários".

Portugal possui dois exemplos muito particulares: Lisboa, crônica anedótica (1930), de Leitão de Barros, e Douro, faina fluvial (1931), de Manoel de Oliveira. Particulares porque a identidade dos contrários neles é bastante acentuada, uma vez que os filmes se debruçam, ao contrário dos exemplos da Alemanha, da Rússia e da França, sobre corpos que vivem, em sua maioria, ainda de forma tradicional, num contexto em que o desenvolvimento tecnológico e os dispositivos técnicos são ainda novidade. ${ }^{7}$

6. Um dos exemplos mais conhecidos é a montagem de imagens de Alexander Kerensky, primeiro ministro do governo provisório, e de um pavão mecânico para comentar sobre a função de marionete política desse personagem histórico. 


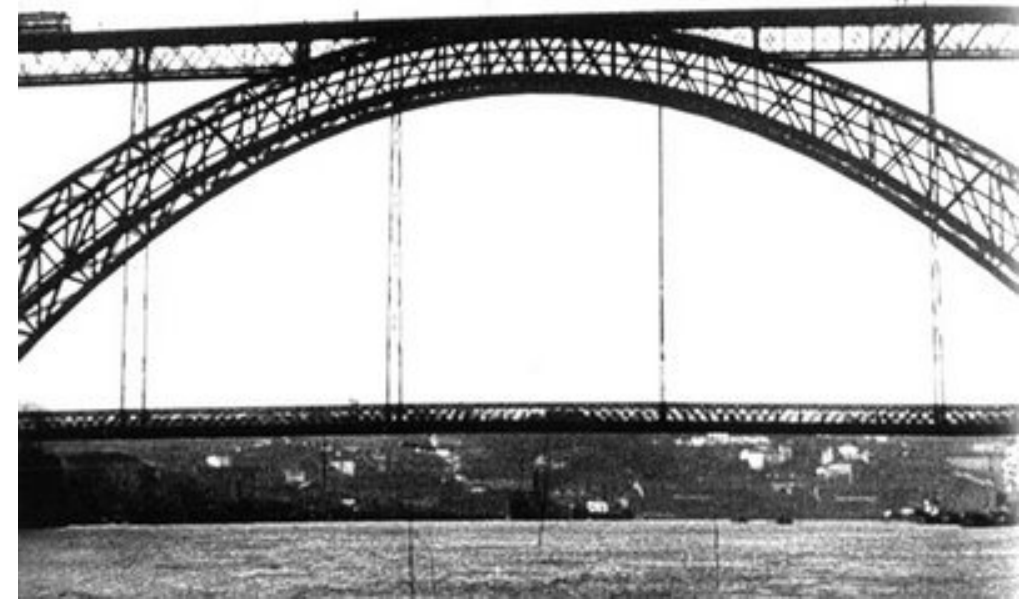

Figura 1: Ponte Dom Luís I e vida na Ribeira em Douro, faina fluvial (Cinemateca Portuguesa)

No filme de Manoel de Oliveira, a câmera explora nos primeiros minutos a construção de filigrana de ferro da ponte Dom Luís I, erguida entre 1881 e 1888 e elaborada por um engenheiro belga e sócio de Gustave Eiffel, Teófilo Seyrig. A obra surge como marco de uma modernidade que convive pacificamente com a vida ainda tradicional na Ribeira do Douro. Contudo, uma das sequências mais famosas do filme de Manoel de Oliveira demonstra a variação sinfônica sobre essa cidade na periferia da Europa, já que realça o fator humano por meio do acaso e da distração. Esse fator é especificamente importante num momento em que as máquinas mecânicas ganharam relevo nos trabalhos diários. Na cena indicada, o equilíbrio entre modernidade e mundo tradicional sai momentaneamente do eixo.

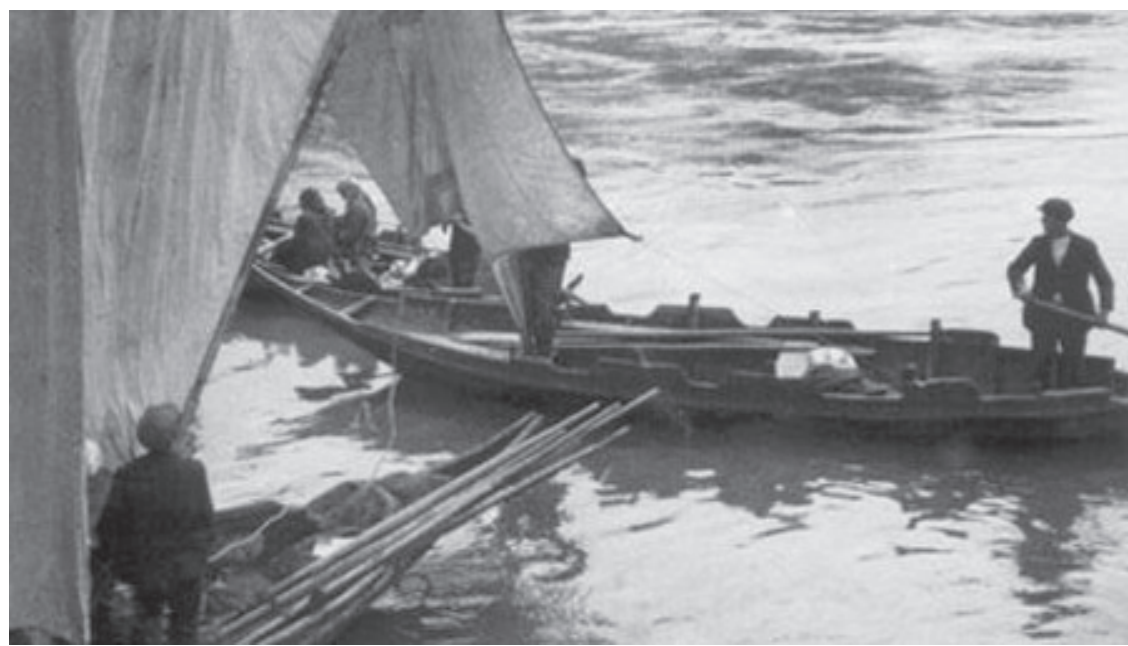

Figura 2: Trabalho na Ribeira em Douro, faina fluvial (Cinemateca Portuguesa) 
ano 1 número 2

Temáticas

Livres

A ação fragmentada através de cortes rápidos mostra como um rapaz que conduz um carro de boi acaba sendo vítima de um descuido de um motorista de caminhão estacionado ao lado dele. O incidente é causado pelo aparecimento de um meio de transporte ainda pouco comum, um avião, que atrai a atenção dos trabalhadores na ribeira do rio portuense. Cortando entre planos do avião voando e dos olhares dos trabalhadores (inclusive do rapaz), detalhes dos gestos do motorista que está arrancando com o caminhão e closes de seus olhares para o céu, constrói-se o desleixo. Desatento, o motorista deixa rolar as rodas do caminhão para trás, empurrando assim o carro de boi. Quando freia, já é tarde demais: assustados, os bois começam a correr, seguidos pelo rapaz que, ao tentar controlá-los, cai e é atropelado por eles. Para dar ao acontecimento a conotação de força da natureza desenfreada, são intercalados imagens de ondas quebrando e, para aumentar a sensação de perigo na corrida, planos de apitos de navios.

No momento do clímax, quando o rapaz cai, vemos um close de uma mulher gritando, o que reforça o dramatismo. O acontecimento gera solidariedade: os trabalhadores abandonam seus lugares de trabalho para socorrê-lo. A desatenção e a "vida própria" da máquina e dos bois causam uma breve perda de ordem que culmina no gesto repreendedor e vingativo do rapaz que pega um pau para bater nos animais. Mas a ordem é reestabelecida quando um policial surge em câmera baixa, anunciado e acompanhado por planos de um apito de navio e de uma locomotiva. O rapaz retorna em seguida para os bois e, arrependido, encosta o seu rosto num deles. $\mathrm{O}$ animal o lambe carinhosamente, enquanto os trabalhadores voltam ao seu trabalho pesado. 


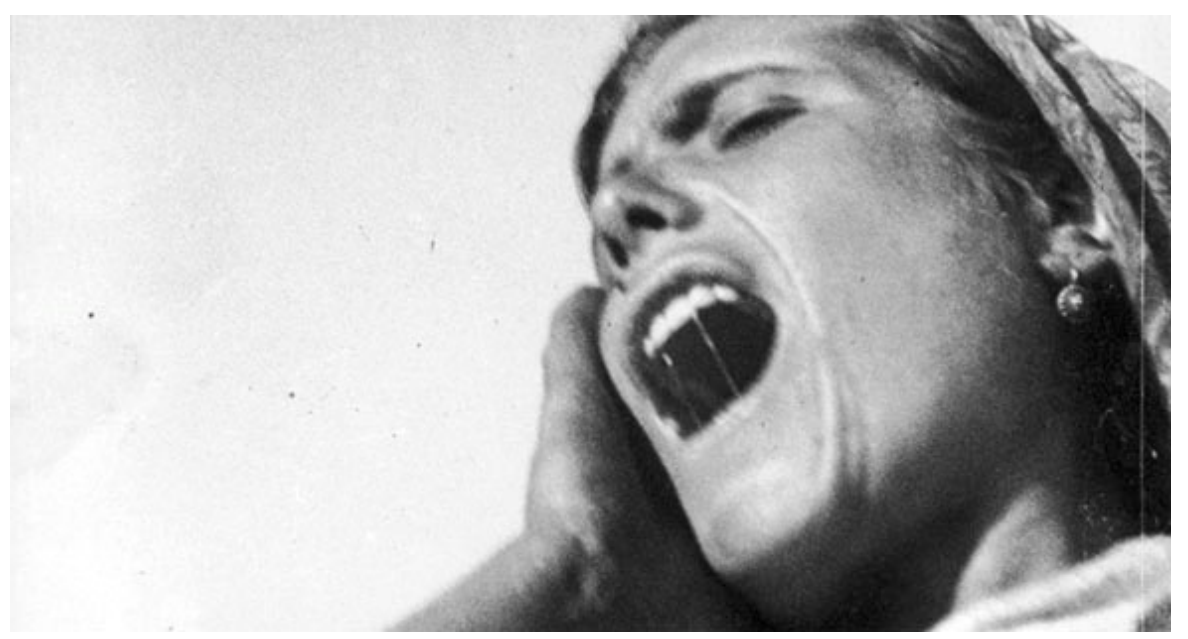

Figura 3: Grito em Douro, faina fluvial (Cinemateca Portuguesa)

Nessa sequência, que demora apenas 90 segundos, mas que possui inúmeros planos que a despedaçam, está contida uma percepção do mundo em vias de industrialização que parte do princípio de que não há hierarquias, nem entre os diferentes meios de transporte que representam temporalidades diversas nem entre os elementos dos planos que compõem a sequência. Tanto boi quanto caminhão são imprevisíveis, e um plano de uma onda ou de um apito possui tanto potencial narrativo quanto uma sequência de planos que constrói uma história inteligível. O dissenso do filme diz respeito à glorificação da tecnologia como avanço da humanidade e se constrói através da experiência de um olhar duplo, atento aos avanços milagrosos da engenharia, mas também aos seus limites, que resultam do seu emprego humano, ou seja, são sujeitos ao acidental. A dimensão afetuosa entre homem e bicho, cujo relacionamento é selado pelos gestos mútuos, reforça essa leitura.

\section{Acto da primavera}

Com base nessa análise, é possível argumentar que o cinema indisciplinar português já marcava presença no cinema mudo. Não há duvida, no entanto, de que o cinema sonoro significou, mundialmente, um maior interesse na construção de narrativas sequenciais, bem como na classificação da nova arte em gêneros, 
ano 1 número 2

Temáticas

Livres

para facilitar o seu consumo em massa. Em Portugal, a comédia musical e o filme rural foram os gêneros mais significativos. Mas os filmes dos anos 30, inclusive o primeiro sonoro, A severa (1931), manifestam certa resistência a abrir mão do cinema como espaço de dissenso que revela a identidade dos contrários, principalmente aqueles realizados por Leitão de Barros, em que a autonomia da imagem convive com a exigência de contar uma história.

O cinema indisciplinar teve algumas aparições pontuais, sobretudo, através de curtas e médias-metragens de Manoel de Oliveira, como $O$ pintor e a cidade (1956), O pão (1959), A caça (1964) e As pinturas do meu irmão Júlio (1965). Acto da primavera (1963) marca, aliás, a manifestação da indisciplinaridade em formato de longa-metragem. Deparamo-nos novamente com a copresença de temporalidades. O cineasta assistiu à representação de um auto em Trásos-Montes, com base no qual encenou com os aldeões uma versão diferente, que aproveita o original, mas o elabora, incluindo cenas contemporâneas que dialogam com o texto em que se baseia, o dramático-religioso Auto da Paixão de Jesus Cristo, fixado por Francisco Vaz de Guimarães no século XVI a partir dos Evangelhos. Há uma coexistência da razão dos fatos (a filmagem de uma encenação centenária) com a razão da ficção (as cenas em que os aldeões atuam), como também do cotidiano com o sagrado e do passado com o presente, principalmente no início e no final do filme, em que Oliveira estabelece um vínculo estreito entre a Paixão e a realidade da aldeia.

Retomo o epílogo que se segue à cena da sepultura representada pelos aldeões para apontar em pormenor como Oliveira trabalha a questão da cotemporalidade. Na sequência já referida, a contemporaneidade irrompe com força na aldeia transmontana, associando diversos níveis temporais à representação do auto. A montagem de imagens de atualidades, com momentos de algumas das maiores guerras do século XX, incluindo a famosa cena da nuvem em forma de cogumelo da bomba atômica que é sobreposta ao rosto de Cristo. Essa atualização da “descida ao inferno", que marca a passagem para a ressurreição na Bíblia, relaciona através das imagens escolhidas o sofrimento das vítimas de guerra com 
o de Cristo. Consequentemente, a montagem não é apenas, como sugere Randal Johnson (2009: 93), um "comentário dos ideais cristãos e do mundo moderno", mas, de fato, é a representação da possibilidade da repetição do milagre da ressurreição e, com ela, da redenção do ser humano no meio dos pecados e da devastação do mundo contemporâneo.

Isso fica evidente em dois momentos específicos. Primeiro, quando os aldeões, que leem no jornal uma notícia sobre a ameaça da bomba nuclear, no final da montagem, são interrompidos por um deles, que estava sendo barbeado. Ele anuncia, como se fosse novamente a representação do auto medieval, o retorno de Jesus. Ao contrário do início do filme, em que Oliveira mostra-se dirigindo a filmagem, aqui o processo da revelação da representação é invertido. Dentro da distanciação criada pela montagem, surge a construção de uma cena que imita a realidade dos aldeões, e nela irrompe agora a "peça", que, paradoxalmente, se torna um anúncio que pode ser percebido pelos presentes como sendo parte da realidade, devido à transferência da representação do auto para a vida cotidiana da aldeia, mesmo que representada. O ficcional - claramente exposto - possui nesse momento específico a qualidade do real (no sentido literário e psicanalítico).

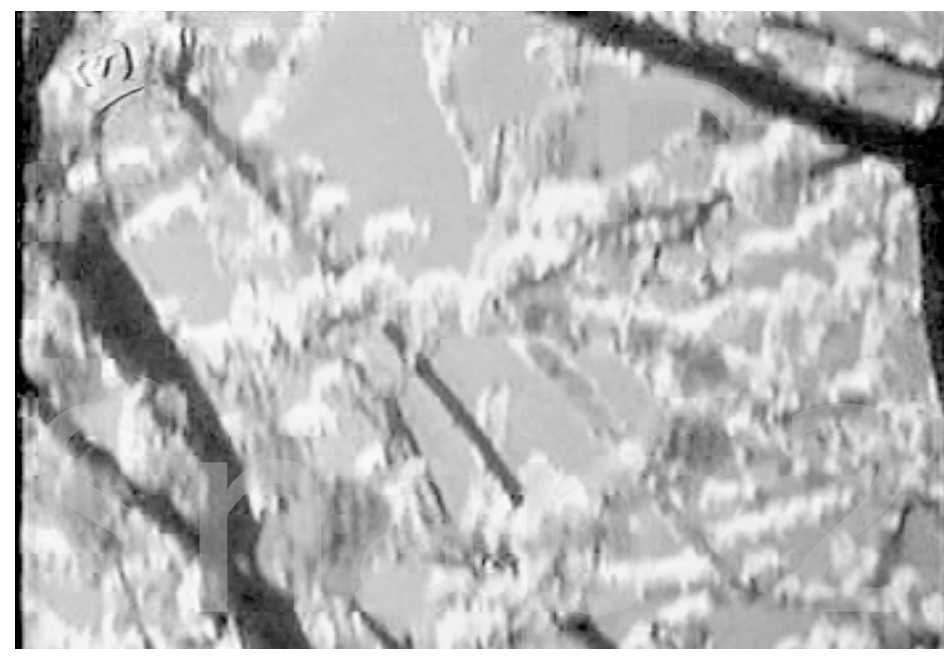

Figura 4: Acto da primavera (Cinemateca Portuguesa)

O segundo momento consiste na promessa simbólica da ressurreição através da imagem da árvore em flor que fecha a montagem das atualidades, indicando 
ano 1 número 2

Temáticas

Livres

que o local remoto, onde os aldeões representam a cada ano o auto que Oliveira filma como representação, ocupa, na verdade, um espaço de copresença temporal. Esses aldeões surgem, portanto, como os verdadeiros representantes da Paixão, isto é, a preservação do auto medieval possui um poder "mágico": estamos num local permeado pelo universal, onde a presença divina de Cristo e a promessa da redenção foram conservadas em seu estado mais puro.

O filme é, de fato, sempre duas coisas ao mesmo tempo: uma leitura muito singular dos limites da representação, tema favorito do pós-modernismo lyotardiano, mas também a afirmação do cinema como véu de Verônica, em que se impregna a realidade no sentido bazaniano. Só que não temos apenas a imagem de Cristo gravada na película cinematográfica, mas, devido à sua possível extensão, toda a Paixão. Poucos filmes reinventaram a relação entre uma situação (a simples apresentação de um auto), a sua visibilidade (a exposição dos elementos anacrônicos dela, a sua filmagem e a sua relação com o mundo dito moderno) e a sua dimensão como pensamento, como esse: é um filme sagrado que comete o sacrilégio de usar a indisciplinaridade cinematográfica para afirmar a presença de Cristo em Trás-os-Montes, bem como em todas as coisas.

\section{Catembe}

Enquanto os limites da condição humana, em seus desdobramentos metafísicos, sociais e históricos, servem como fio condutor de quase todos os filmes de Manoel de Oliveira, a geração seguinte preocupa-se principalmente com o impasse entre atividade e passividade ou, como diria o filósofo José Gil (2004), entre inscrição e não inscrição na sociedade portuguesa da época. Belarmino, de Fernando Lopes, e Verdes anos, de Paulo Rocha, ambos de 1963, são os primeiros filmes a lidar com esse empate, e Uma abelha na chuva (196871), de Lopes, e Brandos costumes (1972-75), de Alberto Seixas Santos, serão as obras-primas desse momento. Há dois cineastas muitas vezes esquecidos nesse 
contexto: António de Macedo, cujo Domingo à tarde (1965) deveria constar aqui, bem como António Campos, o amador de Leiria, que fez, entre outros, $A$ invenção do amor (1966), filme importante não apenas pela sua ousadia política mas também pela audácia ético-estética.

Outro filme singular e o único a ter sofrido cortes violentos é Catembe (1965), de Faria de Almeida. A hipocrisia do olhar português sobre a África, patente em filmes como Feitiço do império (1940), de António Lopes Ribeiro, Chaimite (1953), de Jorge Brum do Canto, e Chikwembo - Sortilégio africano (1953), de Carlos Marques, surge através da desconstrução de uma suposta reportagem sobre uma praia perto de Maputo, na altura de Lourenço Marques. Hoje, seria chamado de mockumentary. Estruturado com a montagem de acontecimentos cotidianos e de entrevistas ao longo de sete dias, o filme trilha um novo caminho para as sinfonias das metrópoles referenciadas acima.

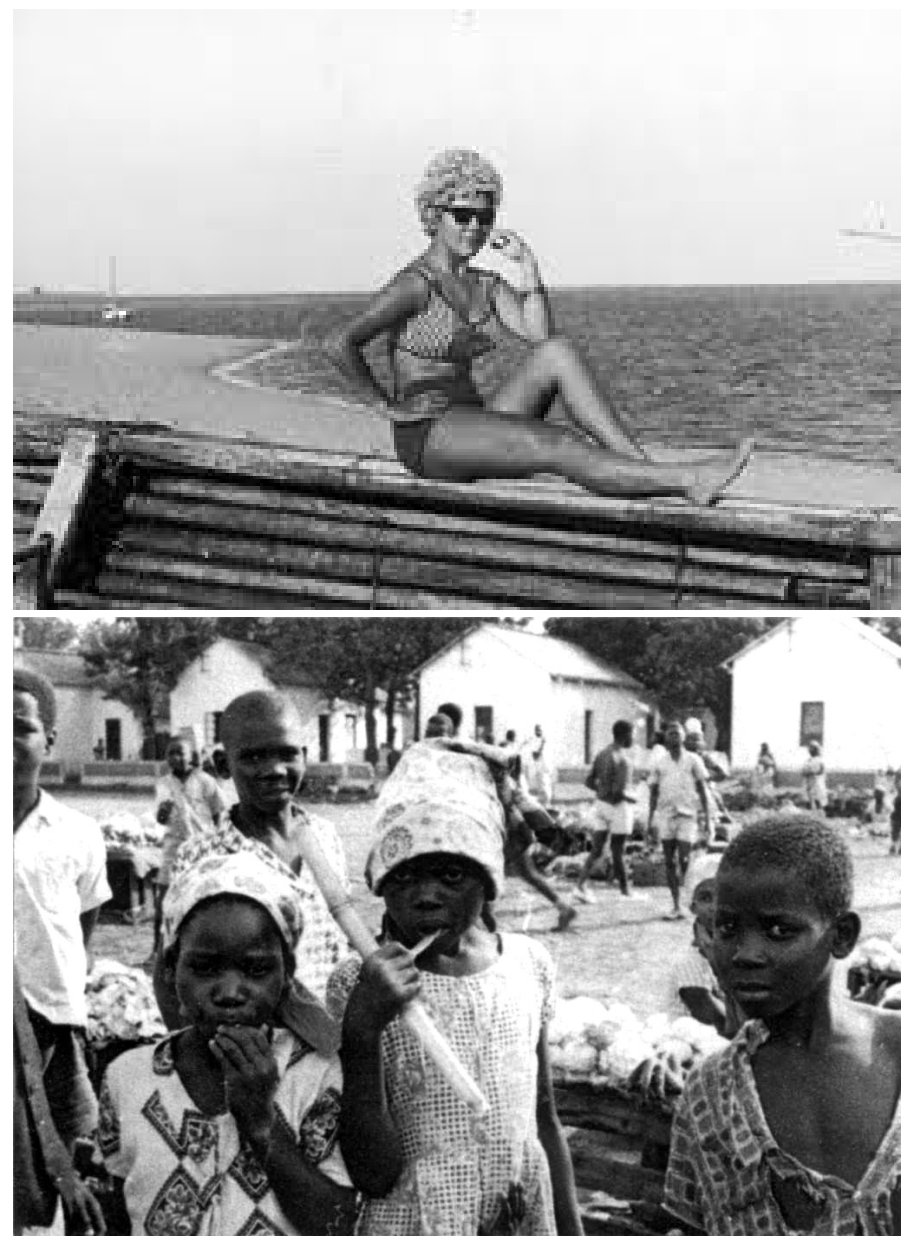

Figura 5: Portugueses e africanos em Catembe (RTP) 
ano 1 número 2

Temáticas

Livres

O dissenso articulado pelo filme, que baralha a razão dos fatos com a razão das ficções, incomodou profundamente, porque tornou perceptíveis as contradições do olhar e dos discursos oficiais sobre as províncias ultramarinas africanas. Embora o filme tenha sido financiado pelo fundo oficial do governo salazarista, o parecer da censura especifica os pontos de dissenso que tinham que ser eliminados:

[...] II. A convivência racial é um tema francamente mal explorado. Não se poderá dizer que haja, a este respeito, imagens 'muito convenientes' mas também se desaproveita a oportunidade de mostrar imagens 'convenientes', aliás, relativamente fáceis de recolher (as escolas, liceus e actividades desportivas permitem, sempre, óptimas imagens quanto a este aspecto). Referem-se, porém, por parecerem de alguma inconveniência os aspectos seguintes: a) está dado, com demasiada nitidez, o contraste entre o 'domingo' (o filme é repartido pelos sete dias da semana) - em que se demonstram o descanso e prazeres de 'brancos' - e a 'segunda-feira' que começa por mostrar o trabalho quase só de 'pretos'. A demasiada nitidez deste contraste pode ser 'amaciada' com uma simples alteração de montagem, que o produtor se declara plenamente disposto a fazer. b) Cenas finais, passadas, em 'cabarets' embora mostrando 'brancos' e 'pretos' parecem igualmente inconvenientes pois não se afigura que reflictam o melhor tipo de relações que podem estabelecer-se. c) O contraste entre a 'opulência' da cidade e a 'pobreza' de Catembe também deveria ser atenuada pelo texto - e não é (apud PIÇARRA, 2009: 241).

Mesmo com 103 cortes de censura, que diminuíram o filme de 80 para 47 minutos, a segunda versão da obra foi proibida. Não por acaso; na versão cortada - que pode ser vista, com um vídeo que contém os cortes, no ANIM (Arquivo Nacional da Imagem em Movimento), da Cinemateca Portuguesa -, é possível notar como Faria de Almeida torna perceptível a desconfiguração do suposto consenso sobre as colônias como lugar idílico. Um dos elementos mais fortes do filme é a música popular alegre, que cria um tom de deboche na tradição da 
montagem horizontal de Chris Marker. As sequências que mostram o lazer dos portugueses são exageradas e artificiais, quando comparadas com a realidade dos africanos, sejam eles trabalhadores na construção civil, sejam eles pescadores. Talvez a censura tenha impossibilitado que o trabalho se tornasse um dos filmes mais indisciplinares da ditadura, mas ele segue sendo certamente o mais irônico (característica inusitada no Novo Cinema português, fora os filmes de Manoel de Oliveira), o que lhe custou o direito de ser exibido.

\section{Jaime}

Dois cineastas incontornáveis daquilo que chamo de cinema indisciplinar são António Reis e Margarida Cordeiro, conhecidos internacionalmente por Trás-osMontes (1976). Comentarei Jaime, primeiro média-metragem realizado pela dupla (apesar de Reis aparecer como único diretor nos créditos), no ano da Revolução dos Cravos, 1974. Nesse momento de mudança de paradigma político, o filme participava ativamente da reconfiguração da percepção acerca de oposições binárias julgadas inquestionáveis durante o regime salazarista: a relação entre natureza e cultura, entre loucura e sanidade, entre mundo sagrado e profano.

O ponto de partida do filme são vida e obra de Jaime Fernandes, um camponês beirão, nascido em 1900. Foi internado com esquizofrenia, aos 38 anos de idade, no Hospital Miguel Bombarda, em Lisboa, onde ficou longos 31 anos. Começou a desenhar obsessivamente três anos antes de morrer, em 1968. Seus desenhos e textos de caráter gráfico, realizados com lápis e esferográfica em cadernos, possuem parentesco estilístico com a arte bruta, o fauvismo e o expressionismo. Um dos médicos reconheceu a qualidade deles, guardou alguns e os mostrou a António Reis.

No entanto, o filme não possui interesse nenhum em apenas reconstruir a vida ou a obra dessa figura anônima, que viveu afastada da sociedade quase metade 
ano 1 número 2

Temáticas

Livres

da sua vida. Jaime conjuga planos filmados no asilo onde viveu grande parte da sua vida com imagens captadas em seu lugar de origem, o interior beirão, justapostas com planos que exploram seus desenhos e textos, para refletir sobre a relação entre esses lugares, o impulso criativo do artista e a escolha e a estética dos objetos de seus desenhos.

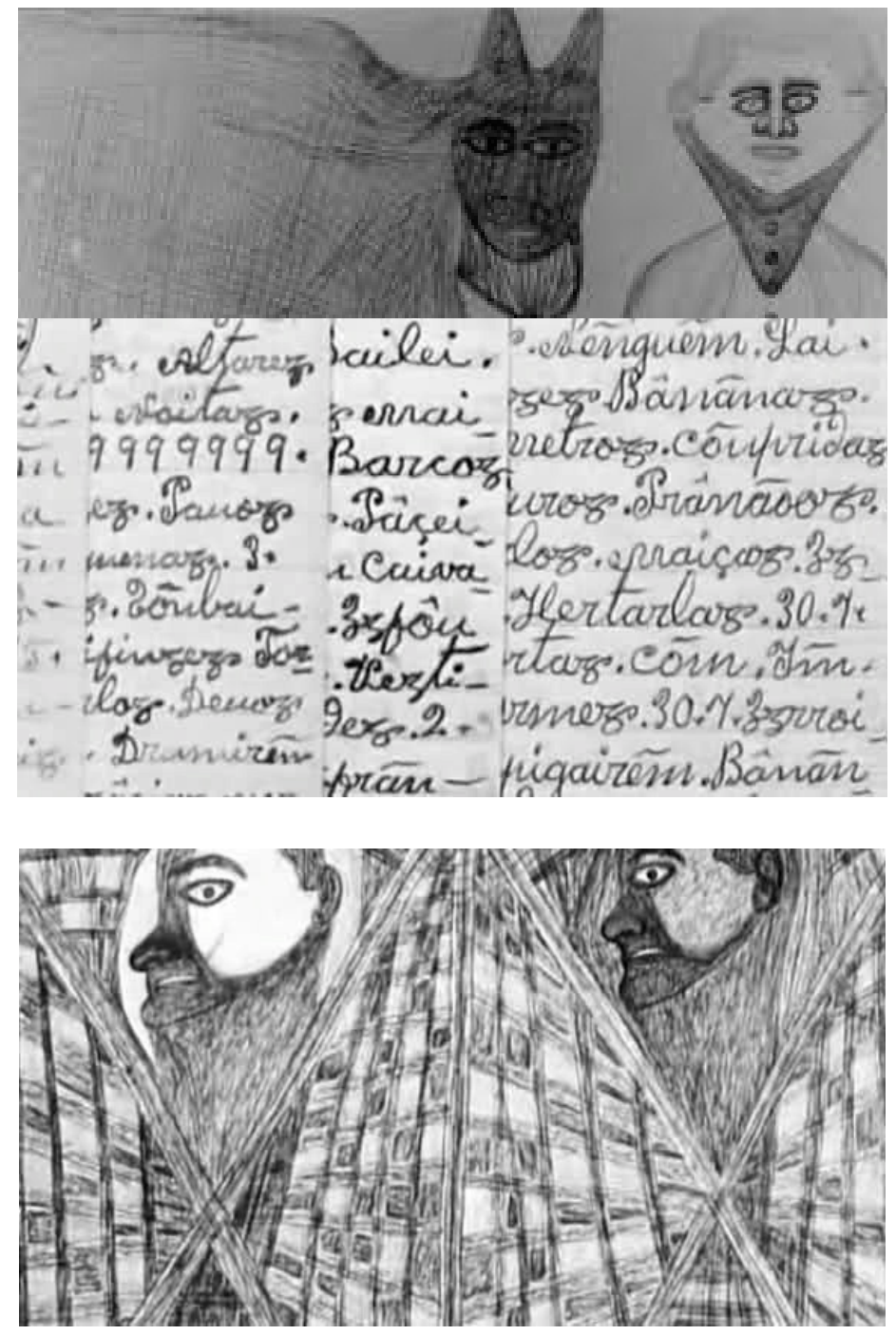

Figura 6: Desenhos e textos em Jaime (Cinemateca Portuguesa)

Para que o espectador possa contextualizar espaços e imagens, há um pequeno texto introdutório depois dos créditos sobre os dados biográficos referidos. Segue um recorte de uma fotografia de Jaime em sépia, que nos confronta com um olhar direto. 


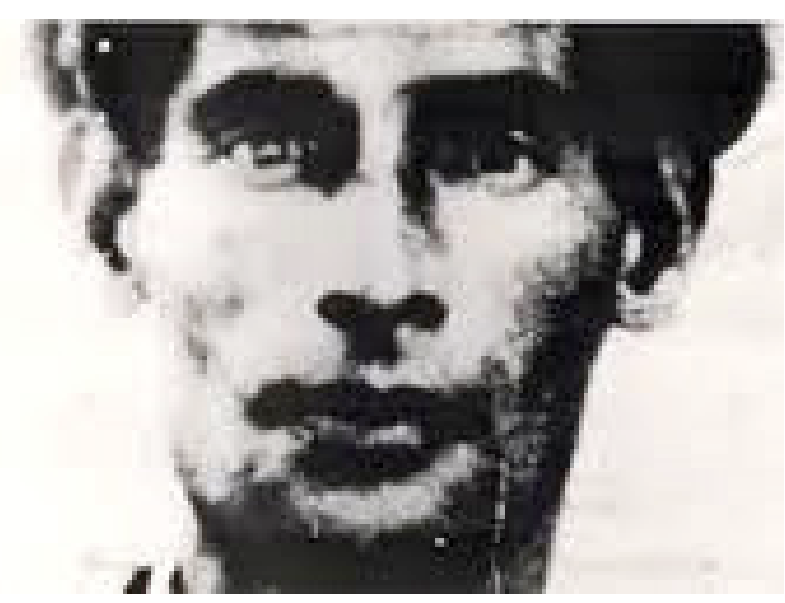

Figura 7: Fotografia de Jaime no filme homônimo (Cinemateca Portuguesa)

O próximo plano é novamente um close - dessa vez, de um dos textos dos cadernos. Através de uma máscara negra, são destacadas as palavras "Ninguém. Só eu". Fotografia e texto expressam logo nos primeiros segundos a identidade de contrários: a singularidade de cada um e também a sua insignificância. A mesma técnica da máscara, só em forma de íris, é utilizada para introduzir o hospital psiquiátrico, com uma panorâmica que revela o pátio circular.

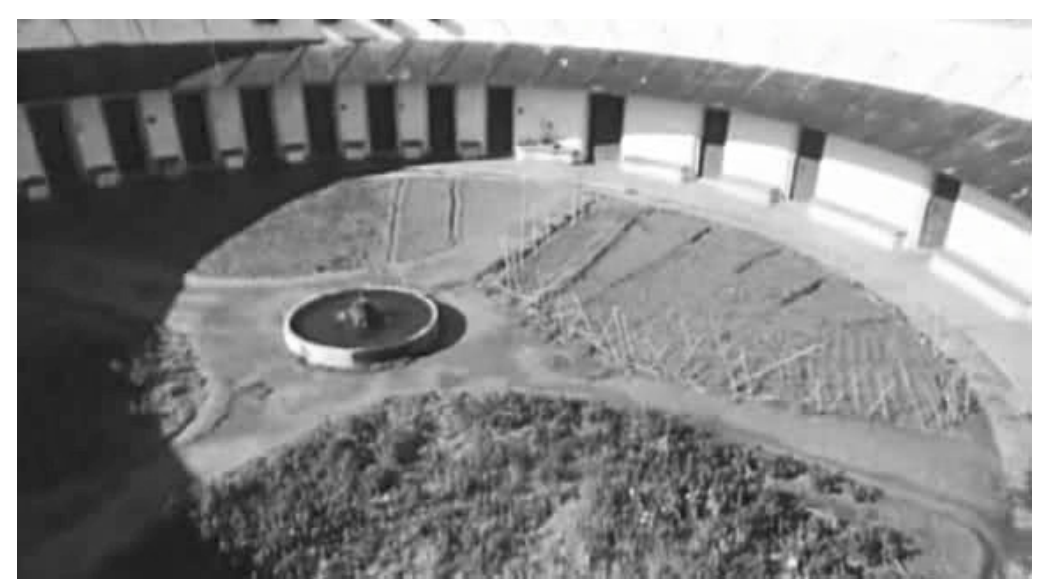

Figura 8: Pátio em Jaime (Cinemateca Portuguesa)

A coloração das imagens imita o sépia da fotografia, remetendo assim ao passado. Mas o insert de um plano fechado de um arbusto colorido anuncia desde logo as sequências que mostrarão a paisagem do mundo rural de 
ano 1 número 2

Temáticas

Livres

onde Jaime era oriundo. A sequência se estende ao longo de dez minutos, exibindo imagens dos internados, que caminham de um lado para o outro, fumam ou brincam com um gato.
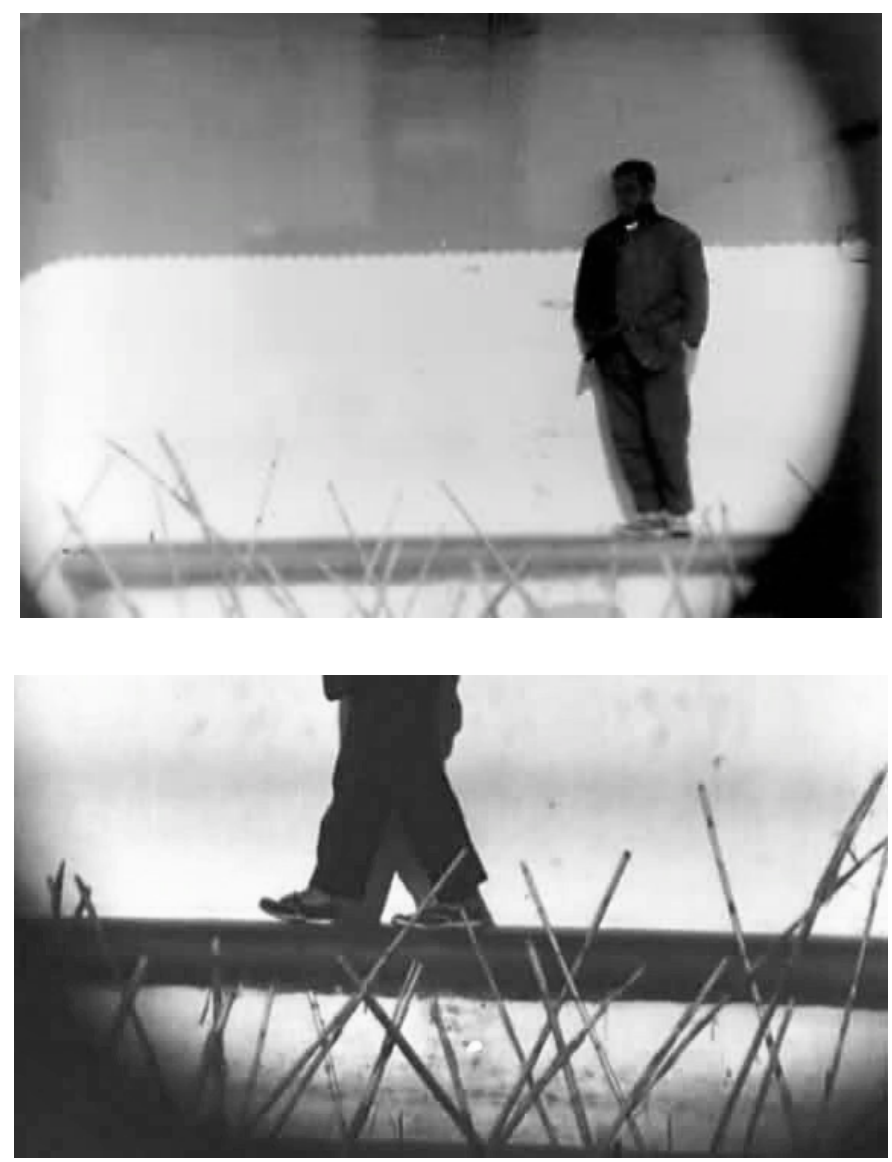

Figura 9: Homem e detalhes dele no pátio em Jaime (Cinemateca Portuguesa)

Muitos dos enquadramentos revelam apenas partes ou sombras das pessoas que vivem da mesma maneira como vivia Jaime. De fato, cada plano remete à seletividade do olhar, sugerindo, desde o início, uma reflexão sobre a relação entre a realidade que nos cerca e as escolhas estéticas nas quais a interpretamos, seja através de planos cinematográficos, seja através de desenhos.

Conhecemos primeiro o pátio e depois o interior do hospital, para, finalmente, vermos o exterior do prédio circular. No interior, a câmera na mão explora o espaço, mas enquadra também imagens que sugerem a presença ou a ausência dos reclusos através de planos que remetem à iconografia da natureza-morta. 
Esses detalhes apontam para um significado não revelado e chamam a atenção não só à materialidade do lugar mas também às histórias, como a de Jaime, que aconteceram ou estão se desenrolando nesse espaço.

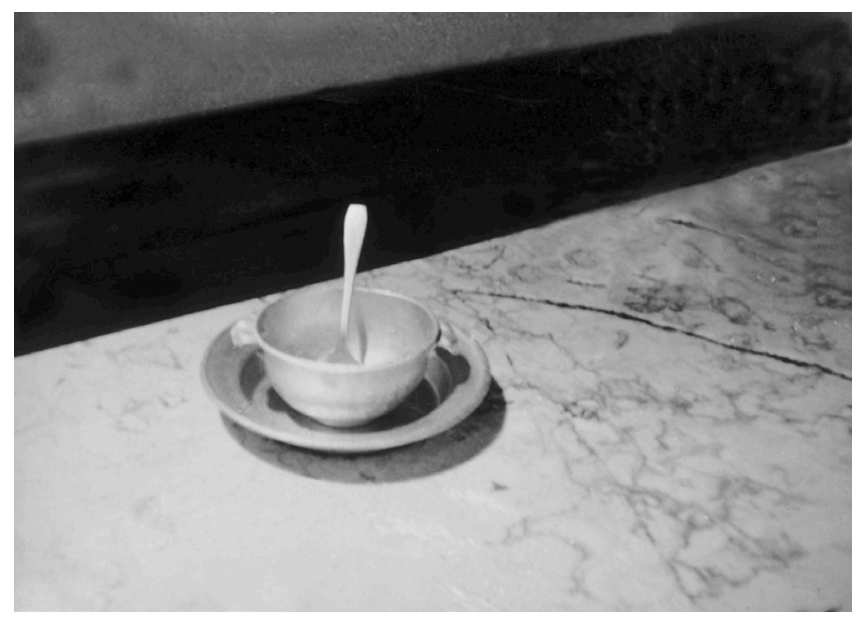

Figura 10: "Natureza-morta" no interior do hospital em Jaime (Cinemateca Portuguesa)

A exploração do interior e a passagem para o exterior são acompanhadas por uma canção interpretada por Louis Armstrong, "St. James infirmary blues", na qual o narrador/cantor relata, ao passo de um ritmo quase fúnebre, que encontrou a amante morta no hospital, atribuindo assim um tom grave e desolado à cena, acrescentando sentimentos e referências sonoras às imagens.

Após obter uma noção do espaço hospitalar onde habitava Jaime, vemos no pátio, no centro do plano, um homem ao lado de uma fonte. Ele veste um gorro e um casaco grosso, enquanto os dois homens, à direita e à esquerda dele, estão vestidos como os internados que vimos antes. Quando ele levanta a mão, a porta do hospital se abre como se fosse por magia, e dela sai um médico, que vem ao encontro da câmera. É um momento que articula a copresença de temporalidades - o mundo pré-científico e o da ciência -, fazendo colapsar as fronteiras entre ambas (e que suscitam perguntas sobre a sua convivência).

A exploração desse tema estende-se para a sequência seguinte, que nos leva para o interior beirão. A câmera entra pela porta do hospital, onde foca uma 
ano 1 número 2

Temáticas

Livres

bacia. Ouvimos o som de um vento forte, e a imagem corta para o interior de uma barca cheia de água que ecoa a forma da bacia. A partir desse momento, o filme mostrará, de modo intercalado e sem truques, o mundo rural e os desenhos e os textos de Jaime. O hospital aparece só duas vezes mais: através de documentos que diagnosticaram a doença de Jaime, exibidos com os textos e os desenhos, e na exposição das obras de Jaime nas paredes brancas de uma das salas do espaço.

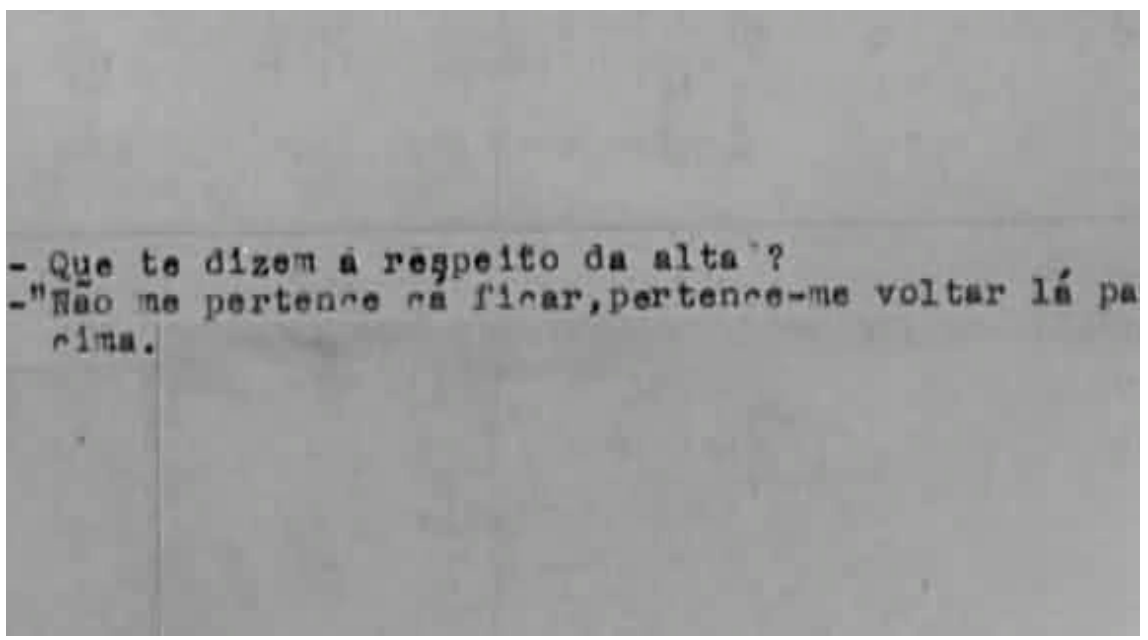

Figura 11: Apontamento de médico em Jaime (Cinemateca)

Não deixa de ser significativo que, para a câmera sair do hospital, onde a sociedade e a sua ciência enclausuram as pessoas, seja preciso mais do que uma montagem cinematográfica - efetivamente, um gesto mágico - que possibilite o acesso ao mundo de origem de Jaime (que coincide com um retorno à natureza). Para Jaime, era claro que não devia pertencer ao hospital - pelo menos é isso que indica o cineasta através da reprodução de uma ficha médica.

Contudo, a natureza não é um lugar bucólico. Os planos mostram animais mortos, e o som do vento aponta para a força desenfreada dela. Essa heterogeneidade caracteriza também a exploração da obra de Jaime. Enquanto planos dos textos nos cadernos são acompanhados pela música suave de Georg Phillipp Telemann, o registro muda para a música atonal e conturbada de Karlheinz Stockhausen quando a câmera enquadra detalhes dos desenhos, revelando de forma fragmentada um vocabulário repetitivo: rostos e corpos de 
homens e de animais; formas geométricas que dialogam não só com os elementos arquitetônicos do hospital mas também com a materialidade do mundo rural.

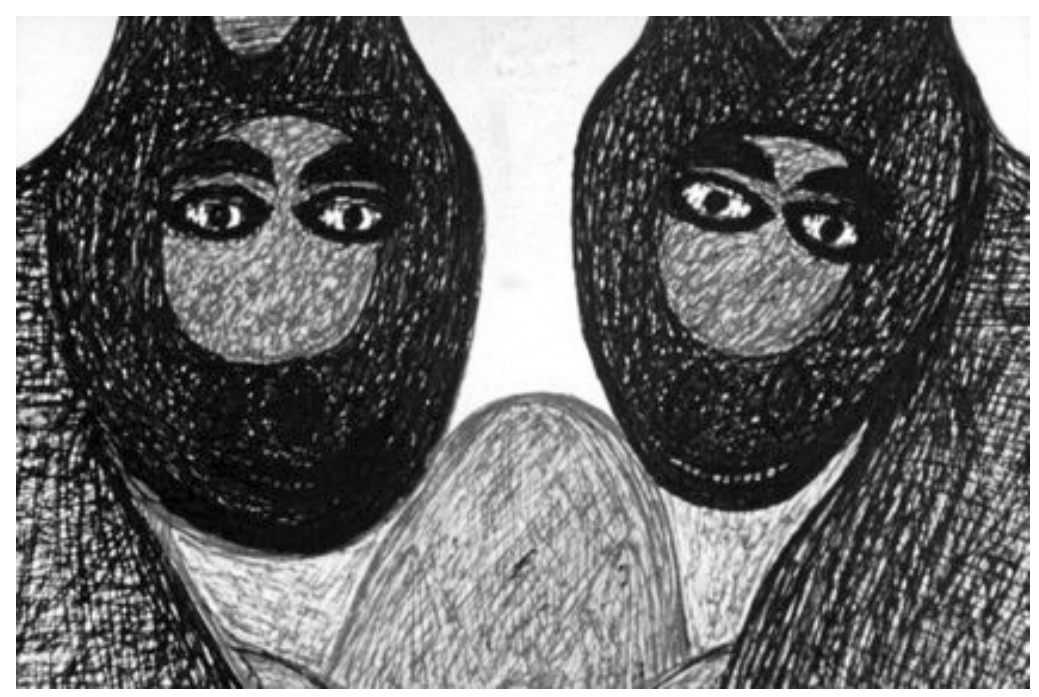

Figura 12: Close de desenho em Jaime (Cinemateca Portuguesa)

A câmera funciona em relação aos quadros como um instrumento de exploração e de amplificação: zooms in e out, movimentos laterais, para cima e para baixo ou na diagonal, enquanto sombreamentos de partes dos textos destacam a materialidade deles. Vemos closes de rostos, de olhos de pessoas e de bichos, de círculos e de grades. Há, de fato, uma analogia entre a maneira como a câmera e a montagem estabelecem uma relação com a realidade, o potencial ficcional dela e a maneira como os desenhos sugerem essa realidade.

António Reis inscreve o seu filme, desse modo, no mesmo regime estético ao qual associa as obras de Jaime. Por um lado, os recortes dos desenhos lembram objetos e figuras dos planos do hospital e do interior do país, que se revelam carregados de significado ou mesmo de pequenas ficções, sem que seja construída uma relação de causa e efeito. Por outro, o filme vai além da analogia e constrói planos que apresentam a presença bruta dos objetos como potencial de significação, ora no interior do hospital, ora no interior do país. 
Em uma sequência de planos, filmada na antiga casa de Jaime, que

ano 1 número 2

Temáticas

Livres

segue a primeira aproximação aos textos e desenhos, vemos, primeiro, um guarda-chuva aberto em cima de grãos de milho; no próximo plano, observa-se um baú aberto e, logo a seguir, vê-se uma máquina de costura cujo enquadramento remete ao segundo plano, com uma sombra indefinível pairando sobre ela. A mesma máquina surge no plano seguinte como um objeto real; porém, as três maçãs penduradas perto da câmera fazem com que o plano tenha novamente uma dimensão simbólica, que introduz um elemento ficcional num contexto supostamente banal.

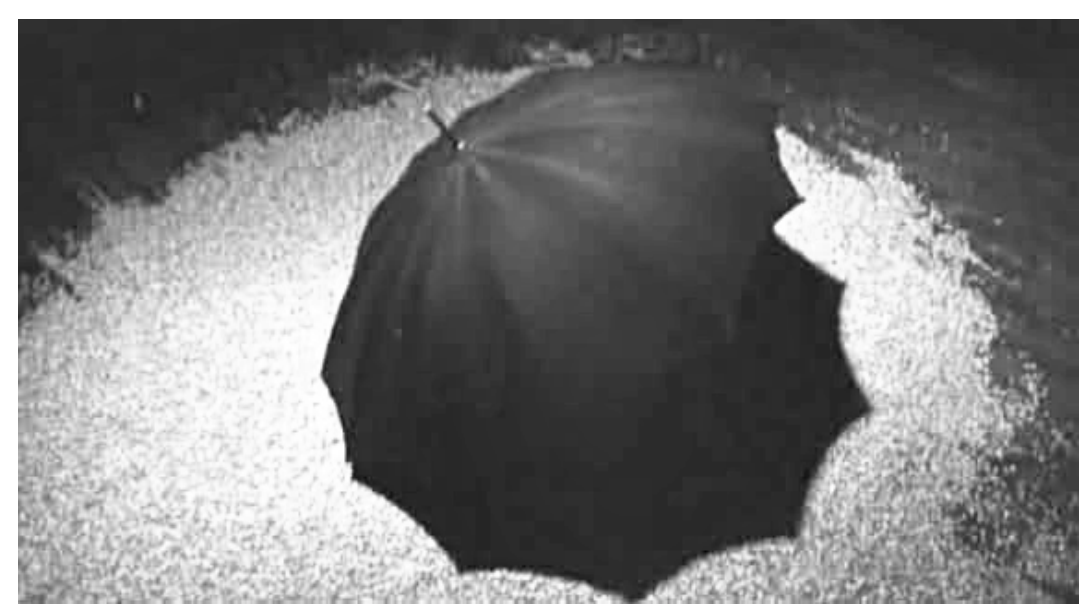

Figura 13: "Natureza-morta" na casa de Jaime (Cinemateca Portuguesa)

No final do filme, a câmera percorre os desenhos expostos nas paredes do hospital, dando a eles o caráter de obras de arte em exposição. Vemos agora na íntegra os animais, individuais ou em grupos, e formas geométricas ou humanas, por meio de uma panorâmica lenta, primeiro para a direita e depois para a esquerda, que nos possibilita a apreciação e a contemplação do trabalho de Jaime. 


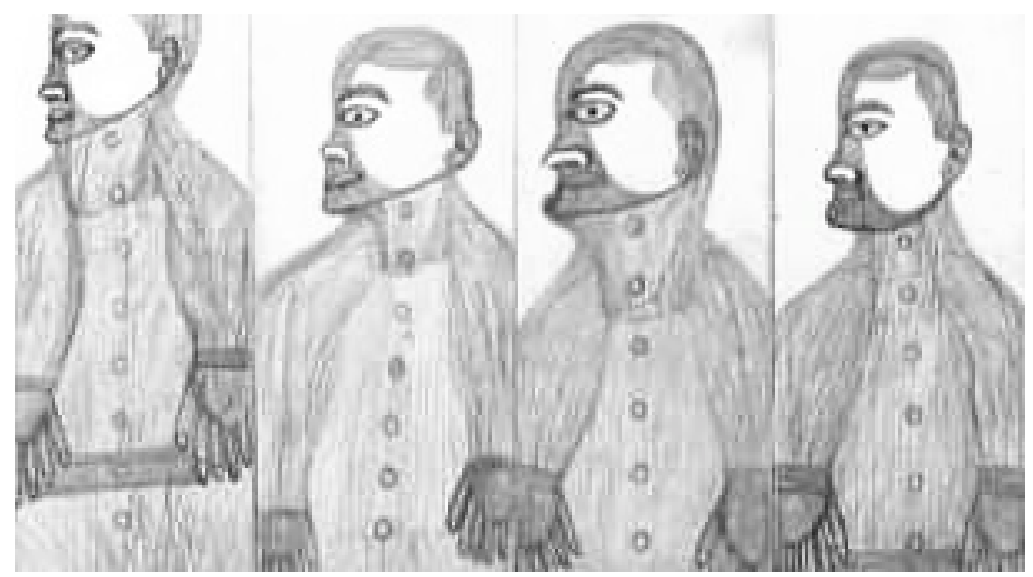

Figura 14: Desenhos expostos em Jaime (Cinemateca Portuguesa)

O último plano enquadra o desenho de uma ave em câmera baixa. A câmera desce e foca uma janela com grade, atrás da qual o céu está de um lilás luminoso. O último corte vai para uma fotografia de Jaime, já velho, olhando para o chão. Assim, o filme acaba como começa, com o reconhecimento da singularidade de uma pessoa capturada na foto. Singularidade essa que engloba agora a qualidade de Jaime como artista, remetendo, ainda, à condição de recluso na qual ele criou a sua arte.

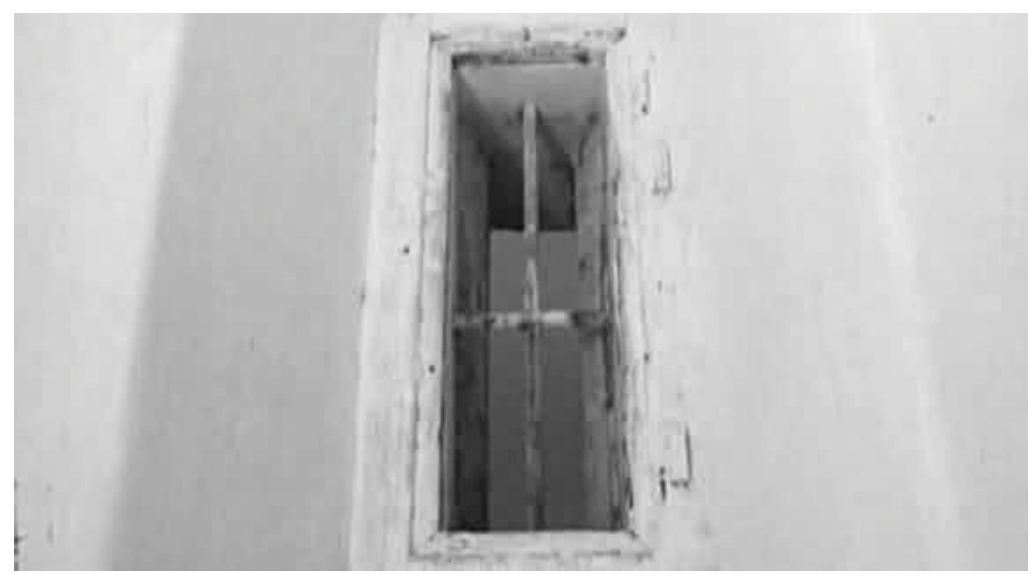

Figura 15: Janela no plano final de Jaime (Cinemateca Portuguesa) 
ano 1 número 2

Temáticas

Livres

Seria fácil pensar numa alegoria da repressão da ditadura através dessa personagem no asilo, mas o filme vai além dessa denúncia. A indisciplinaridade de Jaime consiste em não contar uma história sobre um beirão artista. Em vez disso, realça a relação entre a realidade e a expressão artística, lançando um olhar fragmentado sobre a materialidade do mundo. Com efeito, tudo conta algo sobre Jaime: o pátio, um talher em cima da mesa de um refeitório, uma máquina de costurar, os próprios textos e desenhos. São filmados os lugares onde viveu e que inspiraram a sua obra, mas nunca de forma documental. Assim, torna-se impossível avaliar a relação entre o diagnóstico da sua doença e os bichos e os homens que desenhou. Há apenas pistas. Não há explicações, senão o registro de rastros que, em si, expressam a complexidade das relações entre vida e arte, reconfigurando nossa percepção acerca delas.

\section{Conclusão}

Procurei introduzir neste texto um novo conceito, o de filme indisciplinar, que visa substituir o conceito de ensaio fílmico utilizado desde Eisenstein. Apresentei como argumentos a definição de Deleuze e Guattari do pensar artístico, que torna desnecessário sublinhar a possibilidade de pensar por meio do cinema e a ativação do espectador através de estratégias de montagem assincrônicas, na subjetividade dos autores ou na autorreflexividade. Partindo da indisciplinaridade definida por Rancière, o debate acerca da relação entre realidade e ficção também pôde ser abandonado.

Aplicando o conceito ao cinema português, entendo como filmes indisciplinares as assim chamadas "sinfonias das metrópoles", nomeadamente Douro, faina fluvial, de Manoel de Oliveira, ao debruçar-se sobre a cotemporalidade de formas de trabalho modernas e pré-modernas e sobre a relação paradoxal entre máquina e atuação humana, que se mantém imprevisível também na era da industrialização. 
Acto da primavera parte de uma cotemporalidade parecida, porém, foca a representação cinematográfica. A película registra tanto o físico quanto o metafísico: a representação de um auto e o divino do qual ele parte. Tanto apresenta a perspectiva de que tudo é apenas ficção (através dos espectadores do auto) quanto sugere que se trata de uma manifestação do sagrado e que a "ficção" da redenção é uma possibilidade.

Catembe, por sua vez, desvenda a ficção de uma África paradisíaca. Mesmo com os cortes da censura, o filme interroga o imaginário português acerca das províncias ultramarinas, convidando o espectador a perceber a complexidade da realidade moçambicana, usualmente ignorada pelas reportagens oficiais, que oferecem imagens artificiais de um mundo não existente. Os cortes já despontam a dimensão política do filme, cuja ironia indisciplinar era um dissenso inaceitável.

Como Acto da primavera, simultaneamente pós-moderno e arcaico, Jaime, de António Reis e de Margarida Cordeiro, procura estabelecer relações entre a vida e a percepção dela em sua arte. $\mathrm{O}$ dissenso do filme diz respeito às noções acerca de sanidade e loucura, de cultura e natureza e de vida e arte. Revela a sensibilidade de Jaime e estimula a dos espectadores.

A minha amostra é pequena e abrange apenas quatro filmes portugueses, dos anos 20 até a Revolução dos Cravos. Eles poderiam ser facilmente considerados filmes de autor ou mesmo ensaios fílmicos; porém, chamá-los de filmes indisciplinares evidencia que interrogam esteticamente o consenso do seu tempo acerca de questões políticas: em Douro, faina fluvial, a industrialização; em Acto da primavera, o humanismo cristão numa sociedade em vias de secularização; em Catembe, a romantização do colonialismo; e, em Jaime, a relação entre vida, arte e ciência.

Poderia afirmar que todos esses filmes pensam através de perceptos e afetos, mas isso significaria apenas que são obras da sétima arte. O que os diferencia é 
ano 1 número 2

Temáticas

Livres

o seu afastamento do pensamento disciplinar: eles não definem fronteiras, mas pensam entre os saberes da história, da religião, da sociologia e da medicina. Nos filmes, não há conceitos definidos, nem fatos duros. Eles oferecem sobretudo experiências; experiências que incluem o diretor e o espectador. No caso do primeiro, isso ocorre porque ele procura uma abordagem que contempla a heterogeneidade do mundo, e, no caso do segundo, porque pode acompanhar de forma cognitiva e sensível o espaço entre as oposições binárias através das quais as ciências costumam construir as suas ficções. 


\section{Referências bibliográficas}

ALTER, Nora M. Chris Marker. Urbana; Chicago: University of Illinois Press, 2006.

APRÀ, Adriano (Org.) Le avventure della nonfiction. Roma: Mostra Internazionale del Nuovo Cinema, 1997.

ASTRUC, Alexandre. Nascimento de uma nova vanguarda: a "camera stylo". In: OLIVEIRA, Luis Miguel. Nouvelle vague. Lisboa: Cinemateca Portuguesa, 1999. p. 319-325.

ADORNO, Theodor. "O ensaio como forma". In: ADORNO, Theodor. Notas de literatura I. São Paulo: Editora 34; Duas Cidades, 2003. p. 15-45.

BAZIN, André. "Ontologia da imagem fotográfica”. In: . O cinema: ensaios. Brasiliense, 1991.

BELLOUR, Raymond. L'Entre-Images.Photo.Cinema.Vidéo. Paris: La Différence, 1990.

ROTH, Laurent. Qu'est-ce qu'une Madeleine? A propos du CD-ROM »Immemory« de Chris Marker, Paris: Yves Gevaert, 1997.

BLÜMLINGER, Christa; WULFF, Constantin. Schreiben, Bilder, Sprechen. Texte zum essayistischen Film. Viena: Sonderzahl, 1992.

BRASIL, André. "Ensaios de uma imagem só". Devires, Belo Horizonte, v. 3, n. 1, jan.-dez., 2006.

CORRIGAN, Timothy. The Essay Film: From Montaigne, After Marker. Oxford: Oxford University Press, 2011.

DELEUZE, Gilles; GUATTARI, Félix. O que é a filosofia? São Paulo: Editora 34, 2001.

FRANZ, Artur. “Einleitung”. In: MONTAIGNE, Michel de. Die Essais. Frankfurt am Main: Reclam, 1993. p. 3-26.

GIL, José. Portugal, hoje - O medo de existir. Lisboa: Relógio D’Agua, 2004.

HATTENDORF, Manfred. "Selbstreflexivität und Essayismus im Dokumentarfilm”. In: HATTENDORF, Manfred. Dokumentarfilm und Authentizität. Konstanz: UVK Medien, 1994, p. 258-273. 
ano 1 número 2

Temáticas

Livres

KANZOG, Klaus. "Filmgenres, Strukturkonventionen und Diskurse". In: KANZOG, Klaus. Filmphilologie, München: Schaudig, Bauer, Ledig, 1991. p. 59-67.

KROHN, Bill: “Welles, Fernsehen und der Essayfilm”. In: BLÜMLINGER Christa; WULFF, Constantin (org.): Schreiben, Bilder, Sprechen. Textezum essayistischen Film. Wien: Sonderzahl, 1992. p. 171-177.

LINS, Consuelo. "Dear Doc: o documentário entre a carta e o ensaio fílmico". Devires, Belo Horizonte, v. 3, n. 1, jan.-dez., 2006.

. "Documentário subjetivo e ensaio fílmico". In: . Filmar o real - sobre o documentário brasileiro contemporâneo. Rio de Janeiro: Jorge Zahar, 2008.

LUKÁCS, George. "On the Nature and Form of the Essay: A Letter to Leo Popper", Soul and Form. Cambridge MA: MIT Press, (1978 [1910]), p. 2.

LIANDRAT-GUIGUES, Suzanne; GAGNEBIN, Murielle. L'Essai et le Cinema. Seysell: Éditions Champ Vallon, 2004.

MACHADO, Arlindo. “O filme-ensaio”. Intermídias, 5/6, 2006. Disponível em: www.intermidias.com/miolo/cinema_home.htm. Acessado em: 11 de novembro de 2011.

MIGLIORIN, Cezar (Org.). Ensaios no Real. Rio de Janeiro: Azougue Editora, 2010.

MÖBIUS, Hanno (Org.). Augen-Blick. Versuche über den Essayfilm. Marburg, 1991.

MONTAIGNE, Michel de. Die Essais. Frankfurt am Main: Reclam, 1993.

NOGUEZ, Dominique. "Film-Journal, Film-Collage, Film-Essai". In: ders.: Le cinéma, autrement. Paris: 1977. p. 268-282.

ORTEGA, Maria Luisa,; WEINRICHTER, Antonio (Org.). Mystère Marker. Pasajes en la obra de Chris Marker. Madrid: T \& B Editores, 2006.

RANCIÈRE, Jacques. "Thinking between disciplines? An aesthetics of knowledge”, Parrhesia, n. 1, 2006, p. 1-12. . A partilha do sensível. São Paulo: Editora 34, 2009. . "Política da arte". Disponível em: www.sescsp.org.br/sesc/images/upload/.../206.rtf. Acessado em: 11 de novembro de 2011.

RASCAROLLI, Laura. The Personal Camera: Subjective Cinema and the Essay Film. London; New York: Wallflowerpress, 2009. 
RICHTER, Hans. "Der Filmessay". In: BLÜMLINGER Christa; WULFF, Constantin (Org.). Schreiben, Bilder, Sprechen. Textezum essayistischen Film. Wien: Sonderzahl, 1992, p. 195198.

RIVETTE, Jacques. "Lettre sur Roberto Rossellini”. In: NARBONI, Jean; ROSENBAUM, Jonathan (Org.). Rivette: Texts and Interviews. London: British Film Institute, (1977 [1955]), pp. 54-64.

SCHERER, Christina. Ivens, Marker, Godard, Jarman. Erinnerung im Essayfilm, München: Fink, 2001.

SOLANAS, Fernando; GETINO, Octavio. "Towards a Third Cinema”. In: NICHOLS, Bill (Org.). Movies and Methods, Vol. 1. Berkeley: University of California Press, (1976 [1969]). p. 44-64. XAVIER, Ismail. Teoria e história no estudo de cinema no Brasi - entrevista a Adilson Mendes. In: MENDES, Adilson (Org.). Ismail Xavier. Rio de Janeiro: Azougue, 2009. 